\title{
Formation of sulphuric acid
}

\section{M.H. Rose}

To cite this article: M.H. Rose (1839) Formation of sulphuric acid, Philosophical Magazine Series 3, 15:99, 553-553, DOI: 10.1080/14786443908649955

To link to this article: http://dx.doi.org/10.1080/14786443908649955

册 Published online: 01 Jun 2009.

Submit your article to this journal 준

Џ Article views: 2

Q View related articles $₫$ 
It may therefore be regarded as composed of

One equivalent of chloride of mercury $=238$

One $" \quad$ chloride of sulphur $=52$

A proof of the probability of this view of its nature is the fact already stated, that it may be prepared by the direct action of these compounds on each other.-Journal de Pharmacie, Sept. 1839.

\section{FORMATION OF SULPHURIC ACID. BY M. H. ROSE.}

It is well known that sulphuretted hydrogen gas reduces the higher oxides of some metals to a lower state of oxidation. It is generally admitted that this reduction is derived from the formation of water; and the simultaneous separation of sulphur seems to authorise this opinion. A considerable time since, I observed that in some of these cases sulphuric acid was produced, but which could not be detected in others. This fact gave rise to the following experiments :-

Sulphurctted hydrogen gas does not produce sulphuric acid in a cold solution of sesquioxide of iron. If this oxide, recently precipitated, be dissolved in acetic acid, and a great excess of acetic acid be added to the solution, in order to avoid, as much as possible, the production of sulphuret of iron by the current of sulphuretted hydrogen, no sulphuric acid is found in the solution; nor is there any formed if the solution be heated during the introduction of the gas.

If sulphuretted hydrogen gas be passed into a neutral solution of chloride of iron, or acidified by hydrochloric acid, sulphur only is separated, without the production of sulphuric acid. If, however, the solution be heated while the gas is passing into it, sulphuric acid is formed in the solution, the production of which, under these circumstances, seems worthy of observation. It also takes place when a solution is used which is prepared by treating iron with hydrochloric acid and adding nitric acid, and in employing a pure solution of chloride of iron, and which contains no free chlorine, prepared by heating pure iron in chlorine gas. These solutions had hydrochloric acid added to them, in order to prevent the separation of sesquioxide of iron by ebullition. The formation of sulphuric acid cannot therefore be attributed, in these circumstances, to the admixture of a small quantity of nitric acid. When sulphuretted hydrogen is employed to determine the proportion of sesquioxide of iron contained in a mixed solution of sesquioxide and protoxide, by the quantity of sulphur precipitated, the solution must be used cold. - Journal de Pharmacie, Aout, 1839.

\section{SULPHURETTED HYDROGEN-ACTION ON SOME SALTS OF PO'TASH. BY H. ROSE.}

When sulphuretted hydrogen gas is passed into a dilute solution of chromate of potash, acidulated with acetic acid, no sulphuric acid is formed; the same is the case when hydrochloric acid is employed instead of the acetic, provided the solution be so dilute that the acid 